\title{
Mortal harm and the antemortem experience of death
}

\section{Stephan Blatti}

As James Stacey Taylor correctly notes in his précis, practical ethicists today are engaged in a number of debates that take for granted a couple of ideas whose provenance may be traced all the way back to Aristotle. ${ }^{1}$ The first of these is the thought

Correspondence to Dr Stephan Blatti, Department of Philosophy, University of Memphis, Memphis, TN 38152, USA; blatti@memphis.edu that death (typically) harms the one who dies; call this the 'mortal harm thesis' (MHT). The second is the idea that one can be harmed (and wronged) by events that occur after one's death; call this the 'posthumous harm thesis' (PHT). Taylor devotes two-thirds of his recent book to arguing against both theses and the remainder to working out the implications of their falsity for various bioethical concerns, including euthanasia, suicide, organ procurement, and so on. ${ }^{2}$ Here, I will concentrate on Taylor's case against MHT.

Notwithstanding other suggestions that MHT and PHT stand or fall together (p. 174), ${ }^{3}$ Taylor rightly follows Bradley (p. 44) ${ }^{4}$ in acknowledging the possibility that MHT could be true even if PHT is false. So, having devoted the first four chapters to arguing against PHT, Taylor turns his attention to mortal harm in chapters 5 and 6; here he distinguishes four arguments against MHT. The first two are versions of the famous no-subject argument advanced by Epicurus in his Letter to Menoeceus': the 'hedonic variant' and the 'existence variant.' The 
last two are versions of Lucretius' symmetry argument in his De Rerum Natura ${ }^{6}$ : the 'ontological version' and the 'attitudinal version.'

This looks like a lot of artillery trained on MHT. But it emerges in the course of Taylor's discussion that, in fact, MHT faces not so much a firing squad as a lone gunman. Indeed, the attitudinal version of the symmetry argument aims not at MHT at all, but at assuaging the distress one feels at the prospect of one's death. Taylor sets aside this argument for two reasons: first, it is irrelevant to the bioethical concerns of his book; second, either it is unnecessary (because its conclusion is established by the ontological version) or its conclusion cannot be established (because rational argumentation is ill-suited to assuaging fear) (p. 86). ${ }^{2 \mathrm{i}}$ The ontological version does aim to establish the falsity of MHT. But, as Taylor shows in the remainder of chapter 6 , this argument 'cannot support this conclusion independently' (p. 101). Accordingly, the Lucretian case against MHT stands or falls with its Epicurean counterparts-or rather, counterpart (singular). For in chapter 5 we learn that the existence variant of the Epicurean argument cannot support its own weight either. In order to avoid a problem first raised by Feldman, ${ }^{7}$ Taylor shows how this variant must be revised in such a way that it comes to rely on premise (1) (below) of the hedonic variant of the Epicurean argument (pp. 72-73), with the result that 'the plausibility of the former is derived from that of the latter' (p. 73).

The upshot is this: by Taylor's own lights, the case against MHT ultimately rests with the hedonic variant of the Epicurean argument. Here, then, is his presentation of that argument (p. 70):

1. An event or a state of affairs is a harm to a person only if it adversely affects her experiences.

2. Postmortem persons cannot experience anything.

Thus, given (1) and (2):

3. An event or state of affairs can only harm an antemortem person by adversely affecting her experiences. Thus, from (3):

4. A person can only be harmed by an event or a state of affairs that occurs prior to her death.

${ }^{\mathrm{i}}$ Unless otherwise indicated, all page references are to this work.
5. A person's death does not occur prior to her death.

Thus, from (4) and (5):

A person's death is not a harm to her.

Taylor identifies premise (1) as the linchpin of this argument, and in chapters 3 and 5 he defends it against two main objections: first, against the objection that 'persons can by harmed by events or states of affairs that do not adversely affect their experiences' and, later, against the objection 'that a person's death could harm her in that it deprives her of positive experiences that she would otherwise have had' (p. 82). Since the case against MHT boils down to this argument, Taylor is certainly justified in focusing on what he regards as its most controversial premise.

But I want to focus on a turn in this argument that Taylor regards as utterly uncontroversial, namely the move from (3) to (4). About this inference, Taylor says next to nothing-only that 'premise (4) follows directly from premise (3), which, in turn, follows from the conjunction of premises (1) and (2)' (p. 73). Well, let us assume for the sake of argument that (1)-(3) are true. Does it follow 'directly' that a living person can be harmed by an event or a state of affairs only if that event or a state of affairs occurs prior to the person's death? Not, I suggest, if the event or state of affairs that harms the individual-call her S-just is S's death. Premise (4) follows from (1), (2), and (3) only on the assumption that S's death itself cannot adversely affect S's experiences-on the assumption, in other words, that S's death cannot harm her. Yet this assumption begs the very question at stake in case against MHT.

Now perhaps it will be thought that this assumption is innocuous: S's death is not an event or state of affairs that $S$ herself can experience because its occurrence consists in her non-existence, and one must exist in order to have experiences. But this is too quick. It is possible to accept that (a) S's death consists in her non-existence, that (b) $S$ must exist in order to have experiences and that (c) S's death is an event or state of affairs that she herself can experience, provided one also accepts that (d) one can experience an event or state of affairs prior to its occurrence. ${ }^{\text {ii }}$

ii suspect that Taylor (pp. 14-15) would say that he has established the falsity of (d) with his challenge to Pitcher $^{8}$ and Feinberg ${ }^{3}$ and his case for the impossibility of posthumous harm
Admittedly, spelling out how it is that $\mathrm{S}$ experiences her death before it occurs will take some work that cannot be undertaken in the present context. But here at least is a rough suggestion (no doubt there are other possibilities as well). ${ }^{\text {iii }}$ Because she knows both that human persons will cease to exist when they die (p. 2) and that she is a human person, $S$ knows that she will cease to exist when she dies. She does not know when this event will occur, but she knows both that it will occur and that it can occur at any moment she is living. At any moment of her existence, in other words, $S$ knows that this moment may be her last. It is not implausible, I think, to suggest that the persistent threat of a future event that is certain to occur -S's death-adversely affects S's experiences prior to its occurrence all the while $S$ is living and thinking about it.

Once again, the preceding is just a speculative sketch of how (c) and (d) might be defended. But if it is the case that an event need not occur prior to an individual's death in order to adversely affect her, then premise (4) is false, and Taylor's neo-Epicurean case against the possibility that death can harm the one who dies is seriously threatened. In the meantime, at the very least, it seems to me that (4) begs the question against the advocate of MHT.

\section{Competing interests None.}

Provenance and peer review Commissioned; internally peer reviewed.

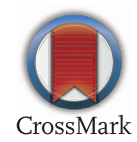

To cite Blatti S. J Med Ethics 2014;40:640-642.

Received 26 May 2014

Accepted 16 June 2014

Published Online First 15 July 2014

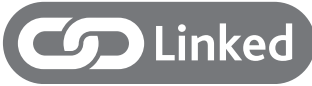

- http://dx.doi.org/10.1136/medethics-2013-101627

- http://dx.doi.org/10.1136/medethics-2013-101755

- http://dx.doi.org/10.1136/medethics-2013-101756

- http://dx.doi.org/10.1136/medethics-2013-101757

- http://dx.doi.org/10.1136/medethics-2014-102336

(chapter 3), and that these arguments would apply mutatis mutandis to mortal harm. I believe this is not the case, but space does not permit me to engage this material here.

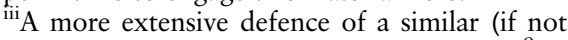
quite the same) suggestion is given by Blatti. ${ }^{9}$ 
Author meets critics: response

J Med Ethics 2014:40:640-642.

doi:10.1136/medethics-2013-101754

\section{REFERENCES}

1 Taylor JS. Death, posthumous harm, and bioethics. J Med Ethics 2014;40:636-7.

2 Taylor JS. Death, Posthumous Harm, and Bioethics. New York: Routledge, 2012.

3 Feinberg J. Harm to Others. In: Fischer J M, ed. The metaphysics of death. Stanford, CA: Stanford University Press, 1993:171-90.
4 Bradley B. Well-being and death. Oxford: Oxford University Press, 2009.

5 Epicurus. Letter to Menoeceus. In: Epicurus: the extant remains. Trans. C. Bailey. Oxford: Clarendon Press, 1926:82-93.

6 Lucretius. De Rerum Natura. Trans. Rouse WHD, rev. Smith MF. Cambridge, MA: Harvard University Press, 2006.

7 Feldman F. Some puzzles about the evil of death. In: Fischer J M, ed. The metaphysics of death. Stanford, CA: Stanford University Press, 1993:305-26.
8 Pitcher G. The misfortunes of the dead. In: Fischer J M, ed. The Metaphysics of Death. Stanford, CA: Stanford University Press, 1993:157-68.

9 Blatti S. Death's distinctive harm. Am Philos $Q$ 2012;49:317-30. 


\title{
JME Mortal harm and the antemortem experience of death
}

\author{
Stephan Blatti
}

J Med Ethics 2014 40: 640-642 originally published online July 15, 2014 doi: 10.1136/medethics-2013-101754

Updated information and services can be found at:

http://jme.bmj.com/content/40/9/640.full.html

\begin{tabular}{cl}
\hline References & $\begin{array}{l}\text { These include: } \\
\text { This article cites } 1 \text { articles } \\
\text { http://jme.bmj.com/content/40/9/640.full.html\#ref-list-1 }\end{array}$ \\
$\begin{array}{c}\text { Receive free email alerts when new articles cite this article. Sign up in } \\
\text { service } \\
\text { the box at the top right corner of the online article. }\end{array}$ & $\begin{array}{c}\text { Topic } \\
\text { Collections }\end{array}$ \\
& $\begin{array}{c}\text { Articles on similar topics can be found in the following collections } \\
\text { JME Author meets critics (25 articles) } \\
\text { Bioethics (153 articles) } \\
\text { Artificial and donated transplantation (139 articles) } \\
\text { Assisted dying (173 articles) } \\
\text { End of life decisions (ethics) (297 articles) } \\
\text { End of life decisions (geriatric medicine) (297 articles) } \\
\text { End of life decisions (palliative care) (297 articles) } \\
\text { Suicide (psychiatry) (109 articles) } \\
\text { Suicide (public health) (109 articles) }\end{array}$ \\
\hline
\end{tabular}

Notes

To request permissions go to:

http://group.bmj.com/group/rights-licensing/permissions

To order reprints go to:

http://journals.bmj.com/cgi/reprintform

To subscribe to BMJ go to:

http://group.bmj.com/subscribe/ 